\title{
標準コアおよび小径コアを用いた 人工軽量骨材コンクリート造建物の耐久性調查
}

\author{
寺田謙一*1・石川雄康*2 ・佐原晴也*3 ・若林信太郎*4
}

\begin{abstract}
概 要 竣工後約 36 年を経過した人工軽量骨材コンクリート造建築物について, 直径 $50 \mathrm{~mm}$ の標準的なコア上直径 $25 \mathrm{~mm}$ の小径コアを用いて, 圧縮強度, 静弾性係数抢よび中性化等の耐久性調查を行った。その結果, 人工軽量骨材コ ンクリートが十分な耐久性を有することが確認できた。また，小径コアを用いて，人工軽量骨材についても普通コンクリー トと同様に，構造体コンクリート強度扔よび中性化を評価できることが確認できた。

キーワード：人工軽量骨材, コンクリート, 而久性, 小径コア, 压縮強度, 中性化, 静弾性係数
\end{abstract}

\section{1.はじめに}

近年，阪神大震災に端を発した耐震安全性への関心， 省資源あるいは社会資本の維持・保全という社会の要請 を背景に，コンクリート構造物の耐久性に関する関心が 急速に高まって扔り，実構造物における耐久性調査が多 く行われている。これらの調查事例はいずれも普通コン クリートを対象としたもので, 人工軽量骨材コンクリー 卜を使用した構造物に関しては，人工軽量骨材が国内に 導入されてからの歴史が浅いこと，また，普通コンクリー 卜と比較すると物件数が少ないことなどから，ほとんど 調查報告のないのが実情である。しかしながら，独立行 政法人建築研究所から「長期間屋外暴露された人工軽量 骨材コンクリートの諸性状 ${ }^{1)}$ が報告されるなど，人工 軽量骨材コンクリートの中長期的な耐久性に関する調查 屯実施され始めている。今般, 竣工後約 36 年を経過し た人工軽量骨材コンクリート造建築物の調査を実施する 機会を得たので，圧縮強度㧍よび中性化等の耐久性調査 を行った。

本調査では一般的に用いられる粗骨材の最大寸法の 3 倍の直径のコアを用いるのと併せて, 構造部材に与える 損傷が軽微なことから普通コンクリート構造物を対象に 普及しつつある小径コア2゙を用いた。すなわち，本調査 は以下の 2 点を主眼において行った。

(1)軽量コンクリートを使用した実構造物の耐久性の確認 (2)小径コア手法の軽量コンクリートへの適用性の確認

\section{2. 調 查 概 要}

\section{1 調査対象施設の概要}

写真-1 に, 調查対象施設の外観写真を示す。



*1 てらだ・けんいち/(有)TRD (正会員)

*2 いしかわ・ゆうこう/太平洋マテリアル(株) 開発研究所 (正会員)

*4 わかばやし・しんたろう/侏錢高組 技術研究所 (正会員)
表-1に, 調査対象施設の概要を示す。施設は琵琶湖 の湖畔に立地している。

表-2に, 使用コンクリートの種類および施工の概要 を示す。

設計基準強度は $18 \mathrm{~N} / \mathrm{mm}^{2}$ であるが，コンクリート の配合に関しては不明である。上部構造に, 粗骨材寸法 が $20 \mathrm{~mm}$ 以下の軽量コンクリート 1 種が用いられてい る。基礎部分のコンクリートは普通コンクリートである。

コンクリートはミキサを用いて現場で混練されており, 骨材は現場に野積みされていたようである。コンクリー トの運搬は一輪車で行い，打ち込んだ後竹棒を用いて締 め固められている。打設時期, 1 回の打設量抢よび養生 方法などは不明である。

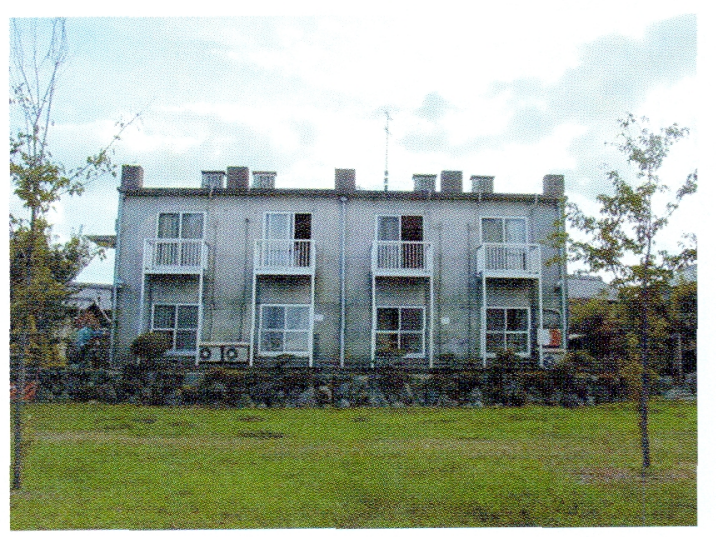

写真-1 調查施設の外観

表-1 調查施設の概要

\begin{tabular}{|c|c|}
\hline 建物名 & 太平洋セメント(㹯)琵琶湖保養所 \\
\hline 建設地 & 滋賀県大津市下阪本 1-32-7 \\
\hline 竣工年 & 1966 年 6 月, 調查時点での経過年数 36 年 \\
\hline \multirow{3}{*}{ 建物概要 } & $\begin{array}{ll} & \text { 本 館： } \mathrm{RC} \text { 造 } 2 \text { 階建て } \\
\text { a) 構造 } \quad \text { 共通館：木造平屋建て }\end{array}$ \\
\hline & b) 建築面積 $219.16 \mathrm{~m}^{2}$ \\
\hline & c) 床面積 1 階: $218 \mathrm{~m}^{2}, 2$ 階: $121 \mathrm{~m}^{2}$, 計 $339 \mathrm{~m}^{2}$ \\
\hline
\end{tabular}


表-2 コンクリートの種類および施工の概要

\begin{tabular}{|c|c|}
\hline コンクリート種類 & $\begin{array}{l}\text { 上部構造：軽量コンクリート1種 } \\
\left(F_{c}=18 \mathrm{~N} / \mathrm{mm}^{2} \text {, 配合詳細は不明 }\right) \\
\text { 基礎部：普通コンクリート }\end{array}$ \\
\hline 骨 & 人工軽量骨材アサノライト $(20 \mathrm{~mm}$ 以下 $)$ \\
\hline 細 & 野洲産川砂 \\
\hline 製 & 現場ミキサ練り $\left(0.4 \mathrm{~m}^{3}\right)$ \\
\hline コンクリートの運搬 & 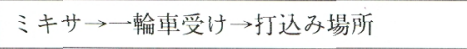 \\
\hline 締固め（充てん方法） & 竹棒による締固め \\
\hline
\end{tabular}

表-3 コア採取箇所および本数

\begin{tabular}{|c|c|c|c|c|c|c|c|}
\hline $\begin{array}{l}\text { 位置 } \\
\text { 記号 }\end{array}$ & $\begin{array}{l}\text { コンクリ } \\
\text { ート種類 }\end{array}$ & 階数 & 部位 & $\begin{array}{l}\text { 環境 } \\
\text { 条件 }\end{array}$ & 方角 & 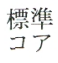 & $\begin{array}{l}\text { 小径 } \\
\text { コ予 }\end{array}$ \\
\hline W-1 & 軽量 & $1 \mathrm{~F}$ & 壁 & 外部 & 北面 & 1 体 & 2 体 \\
\hline W-2 & 軽量 & $1 \mathrm{~F}$ & 壁 & 内部 & 南面 & 1体 & 3 体 \\
\hline W-3 & 軽量 & $2 \mathrm{~F}$ & 壁 & 内部 & 北面 & 1体 & 2 体 \\
\hline W-4 & 軽量 & $2 \mathrm{~F}$ & 壁 & 内部 & 北面 & 1体 & 2体 \\
\hline W-5 & 軽量 & $2 \mathrm{~F}$ & 壁 & 内部 & 南面 & 1 体 & 3 体 \\
\hline $\mathrm{C}-1$ & 軽量 & $1 \mathrm{~F}$ & 柱 & 外部 & 北面 & 1 体 & 2 体 \\
\hline C-2 & 軽量 & $1 \mathrm{~F}$ & 柱 & 外部 & 東面 & 1体 & 4 体 \\
\hline C-3 & 軽量 & $2 \mathrm{~F}$ & 柱 & 外部 & 東面 & 1体 & 2 体 \\
\hline S-1 & 軽量 & $2 \mathrm{~F}$ & 麻 & 外部 & （東侧） & 1体 & 2 体 \\
\hline$N-1$ & 普通 & $1 \mathrm{~F}$ & 基礎 & 外部 & 束面 & 1体 & - \\
\hline
\end{tabular}

\section{2 調 査箇所}

表-3に，コア採取箇所扔よび本数を示す。

写真-2 に, コア採取状況を示す。写真-3に，標準コ アを示す。また，写真-4に，小径コアを示す。

1 階拈よび 2 階の壁，柱，スラブおよび基礎の合計 10 箇所から，直径 $50 \mathrm{~mm}$ のコア（以下，標準コアと呼ぶ） を各 1 本採取した。直径を $50 \mathrm{~mm}$ としたのは，壁厚さ が $15 \mathrm{~cm}$ 程度であり, 直径 $100 \mathrm{~mm}$ では高さ $h$ 之直径 $d$ の比 $h / d=2$ が確保できなかったためである。小径コア は, 直径を $25 \mathrm{~mm}$ とし, 標準コアの近傍から 2 4 本採 取した。

\section{3 試験項目および試験方法}

(1) 標準コア

1）圧縮強度試験

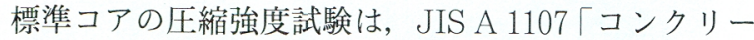

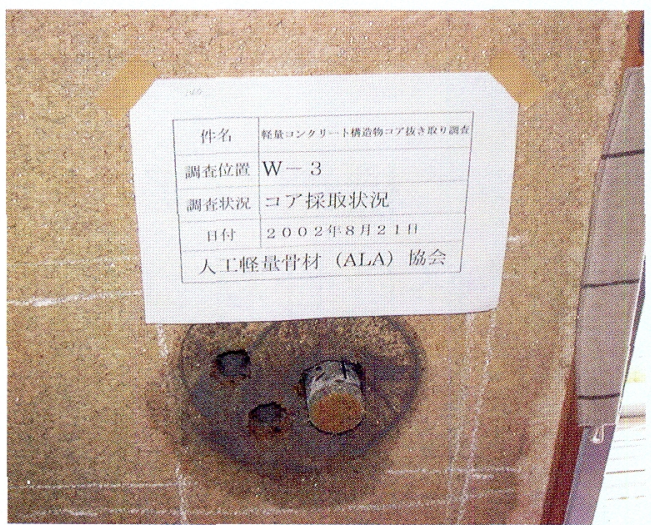

写真-2 コア採取状況（W-3）

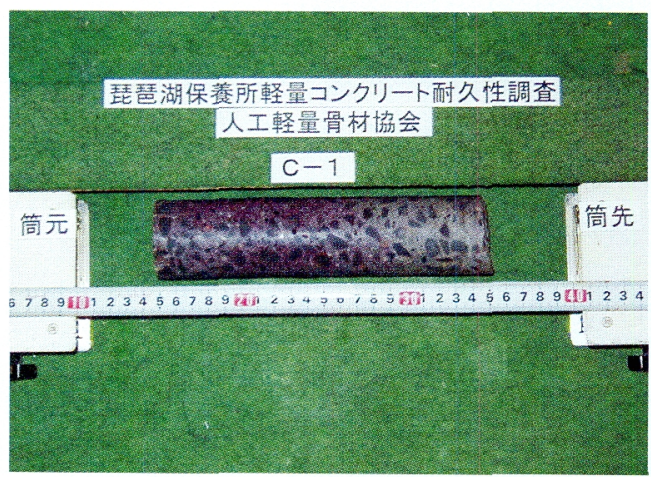

写真-3＼cjkstart標準コア $(\mathrm{C}-1)$

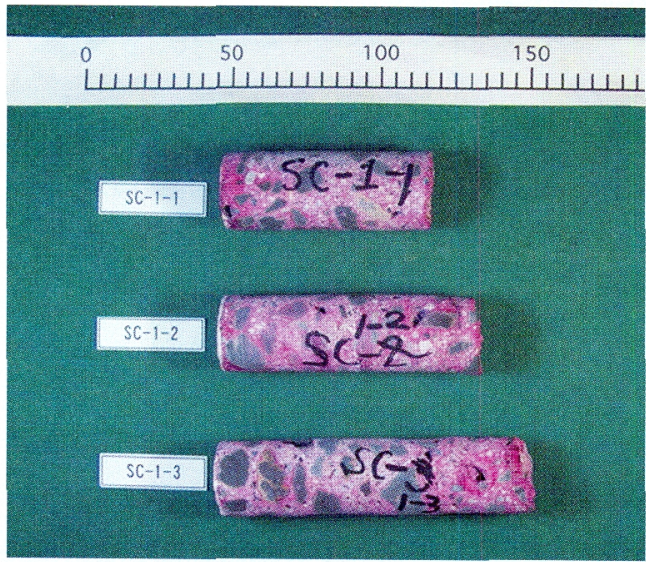

写真-4 小径コア (C-1)

Investigation on Durability of Artificial Light-weight Aggregate Concrete Structure by Standard Size Cores and Small Size Cores

By K. Terada, Y. Ishikawa, H. Sawara and S. Wakabayashi

Concrete Journal, Vol. 42, No. 10, pp. 29 34, Oct. 2004

Synopsis Authors have investigated on compressive strength, Young's modulus and neutralization with standard size cores and small size cores sampled from artificial light-weight aggregate concrete structure aged 36 years. From the results artificial light-weight aggregate concrete is durable, and estimation method for strength and neutralization of concrete in structures by small size cores is applicable not only to normal weight concrete but also artificial light-weight aggregate concrete.

Keywords : artificial light-weight aggregate, concrete, durability, small size core, compressive strength, neutralization, Young's modulus 
トからのコアの採取方法及び圧縮強度試験方法」に準拠 して行った。

2）静弾性係数試験

静弾性係数試験は, JIS A 1149 「コンクリートの静弾 性係数試験方法」に準拠して行った。

3）中性化深さ

中性化深さは, JIS A 1152 「ンクリートの中性化深 さの測定方法」に準拠して行った。なお，測定は側面を 測定面とする方法と割裂面を測定面とする二つの方法で 行った。なお，側面を測定面とする場合は，測定は現地 においてコア採取後直ちに行った。

4) 断面観察

コアの断面を顕微鏡で観察し，ひび割れ等の有無を確 認した。

（2）小径コア

1）圧縮強度

圧縮強度試験用供試体は，採取したコアより，原則と して大きな粗骨材が含まれる部分を避けてキャッピング 後の高さ $h$ 之直径 $d$ の比 $h / d$ が, $h / d=2$ となるように 切り出した後, 供試体の両端面に硫黄キャッピングを施 して作製した。

小径コアの圧縮強度試験は，最大容量 $2000 \mathrm{kN}$ の一 軸圧縮試験機を用いて，載荷速度 $0.25 \mathrm{~N} / \mathrm{mm}^{2} / \mathrm{s}$ の荷 重制御で行い，荷重は容量 $50 \mathrm{kN}$ の荷重計で測定した。

2) 中性化深さ

現地において採取したコアを用いて，フェノールフタ レイン法により，側面を 4 点測定した。

3. 試 験 結果

\section{1 圧縮 強 度}

（1）調查部位ごとの圧縮強度平均值

表-4に，圧縮強度および静弾性係数の試験結果を示す。

図-1に，調查部位ごとの圧縮強度を示す。

調査部位ごとの小径コアと標準コアの圧縮強度差は, 平均值で比較した場合, $-4.6 \mathrm{~N} / \mathrm{mm}^{2}$ から $20.2 \mathrm{~N} /$ $\mathrm{mm}^{2}$ の範囲にある。 $20.2 \mathrm{~N} / \mathrm{mm}^{2}$ と最も差の大きい $\mathrm{C}$ -3に怙ける標準コアは目地部分から採取したコアであ る。C-3 で採取した 2 体の小径コアの強度がほぼ等しい ことから考えて，目地部から採取した標準コアに収縮に よる微細なひび割れ等の局部的な欠陥があったものと推 定される。そこで，これ以降は，C-3の標準コア強度を 除いて検討を行うこととする。

（2）小径コア強度と標準コア強度の関係

図-2 に，C-3 を除く小径コア強度と標準コア強度の 関係を示す。小径コア強度は, 調査部位ごとの平均値と した。図中の実線は線形回帰式を示し，点線はこれまで に提案した小径コアによる普通コンクリートの構造体コ ンクリート強度の推定式 $(1)^{3)}$ において,$h / d=2$ とし た場合の小径コア強度と標準コア強度の関係式である。

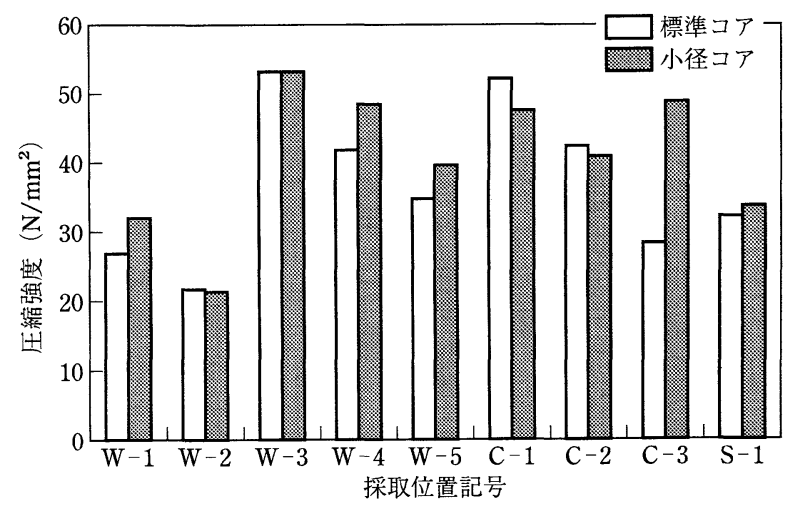

図-1＼cjkstart調查位置ごとの圧縮強度

$$
\hat{X}=x-\left(a-b \frac{h}{d}\right)
$$

ここに, $\hat{X}: \phi 100 \times 200 \mathrm{~mm}$ コア強度の推定值

$\left(\mathrm{N} / \mathrm{mm}^{2}\right)$

$x:$ 小径コア強度 $\left(\mathrm{N} / \mathrm{mm}^{2}\right)$

$\frac{h}{d}$ : 小径コア供試体の高さ $h$ と直径 $d$ の比

$a, b:$ 実験により定められた定数

(ここでは, $a=12.9, b=6.0$ )

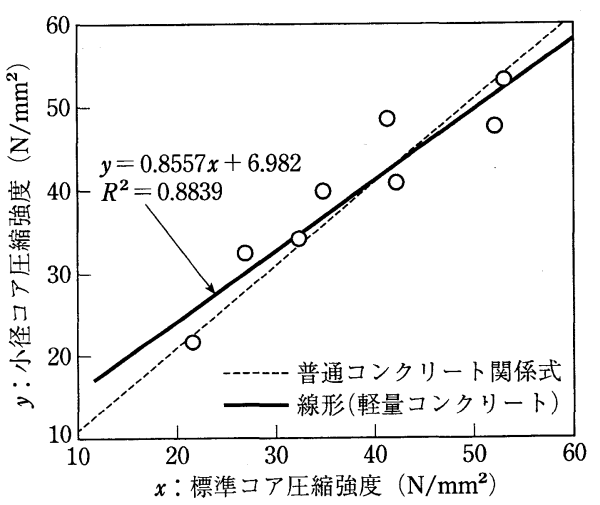

図-2小径コア強度と標準コア強度の関係

図からわかるように，小径コア強度と標準コア強度の 相関は強く, 軽量コンクリートにおける小径コアと標準 コアの関係式は, 普通コンクリートの関係式とほぼ一致 する。よって, 軽量コンクリートについても, 普通コン クリートと同様の方法で, 小径コアによる構造体コンク リート強度の推定が可能である。

（3）建物の圧縮強度の評価

表-4に，普通コンクリートの関係式 (1) を用いて小 径コア強度を標準コア強度に換算したものを補正後強度 として示す。小径コアに関してはこの補正後強度を用い て，施設の圧縮強度の評価を行う。

1）施設全体の強度

表-5に，圧縮強度の母平均の推定結果を示す。

標準コアで推定した施設全体の圧縮強度の母平均は, 38. $3 \pm 9.5 \mathrm{~N} / \mathrm{mm}^{2}$ であり，95\%信頼限界の下限值は $28.8 \mathrm{~N} / \mathrm{mm}^{2}$ である。おなじく, 小径コアで推定した母 
表-4 圧縮強度および静弾性係数の試験結果

\begin{tabular}{|c|c|c|c|c|c|c|c|c|c|c|}
\hline & & & 漂 準 コ ア & & & & 小径コア压縮ら & $\left(\mathrm{N} / \mathrm{mm}^{2}\right)$ & & \\
\hline \multirow[b]{2}{*}{$\begin{array}{l}\text { コンクリ } \\
\text { ート種類 }\end{array}$} & \multirow[b]{2}{*}{$\begin{array}{l}\text { 調査位置 } \\
\text { 記号 }\end{array}$} & \multirow{2}{*}{$\begin{array}{l}\text { 圧縮強度 } \\
\left(\mathrm{N} / \mathrm{mm}^{2}\right)\end{array}$} & \multirow{2}{*}{\begin{tabular}{|c|} 
単位容積質量 \\
$\left(\mathrm{g} / \mathrm{cm}^{3}\right)$
\end{tabular}} & \multirow{2}{*}{$\begin{array}{l}\text { 静弾性係数 } \\
\left(\mathrm{kN} / \mathrm{mm}^{2}\right)\end{array}$} & \multicolumn{3}{|c|}{ 試 } & \multicolumn{3}{|c|}{ 補 } \\
\hline & & & & & 全 試 料 & $\begin{array}{l}\text { 部位ごとの } \\
\text { 平均值 }\end{array}$ & $\begin{array}{l}\text { 小径コアと } \\
\text { 標準コアの } \\
\text { 圧縮強度差 }\end{array}$ & 全 試 料 & 部位ごとの & $\begin{array}{l}\text { 小径コアよ } \\
\text { 標準コアの } \\
\text { 圧縮強度差 }\end{array}$ \\
\hline \multirow{30}{*}{ 軽 量 } & \multirow{2}{*}{ W-1 } & \multirow{2}{*}{27.1} & \multirow{2}{*}{ 1. 94} & \multirow{2}{*}{12.5} & 33.7 & \multirow{2}{*}{32.2} & \multirow{2}{*}{5.1} & 32.9 & \multirow{2}{*}{31.3} & \multirow{2}{*}{4.2} \\
\hline & & & & & 30.8 & & & 29.7 & & \\
\hline & \multirow{3}{*}{ W-2 } & \multirow{3}{*}{21.7} & \multirow{3}{*}{1.94} & \multirow{3}{*}{14.4} & 22.8 & \multirow{3}{*}{21.5} & & 21.6 & & \\
\hline & & & & & 17.4 & & -0.2 & 16. 4 & 20.6 & -1.1 \\
\hline & & & & & 24.6 & & & 23.7 & & \\
\hline & WL-2 & 524 & 107 & 108 & 54.8 & 520 & & 53.9 & & \\
\hline & 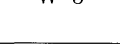 & 00.7 & 1.01 & 10.0 & 51.5 & 00.4 & 0.4 & 50.6 & 0.4 & 1.2 \\
\hline & $W-4$ & 417 & 107 & 189 & 45.8 & 485 & 68 & 44.6 & 475 & 58 \\
\hline & & (1) & 1. & 10 & 51.3 & 70 & 0.0 & 50.3 & T1. & 0.0 \\
\hline & & & & & 43.4 & & & 42.3 & & \\
\hline & W-5 & 34.9 & 1.97 & 17.2 & 40.3 & 39.8 & 4.9 & 39.4 & 38.8 & 3.9 \\
\hline & & & & & 35.7 & & & 34.7 & & \\
\hline & & & & & 58.9 & & & 57.9 & & \\
\hline & $C-1$ & 52.3 & 1.99 & 18. 6 & 50.9 & 47.7 & -4.6 & 50.0 & 46.8 & -5.5 \\
\hline & & & & & 33.3 & & & 32.6 & & \\
\hline & & & & & 48.7 & & & 47.7 & & \\
\hline & $\mathrm{C}-2$ & 4) 5 & 102 & 170 & 33.2 & 40 & 16 & 32.2 & 100 & 0 \\
\hline & & & & & 42.1 & $4 . .5$ & 1.0 & 41.3 & 40.0 & 4.J \\
\hline & & & & & 39.7 & & & 38.8 & & \\
\hline & $C_{-} 2$ & 20 & 103 & 126 & 49.7 & 106 & ת ח & 48.7 & 175 & 10 \\
\hline & 8 & (0. $T$ & 1.50 & 14.0 & 47.5 & 40.0 & 4.4 & 46.4 & 41.0 & 19.1 \\
\hline & & & & & 28.9 & & & 28.2 & & \\
\hline & S-1 & 32.5 & 1.92 & 16.7 & 35.0 & 34.0 & 1.5 & 34.0 & 33.1 & 0.6 \\
\hline & & & & & 37.9 & & & 37.0 & & \\
\hline & 試 料 数 & 9 & 9 & 9 & 24 & 9 & 9 & 24 & 9 & 9 \\
\hline & 平 均 值 & 37.2 & 1.95 & 16.5 & 39.9 & 40.7 & 3.5 & 39.0 & 39.8 & 2.6 \\
\hline & 標準偏差 & 11.1 & 0.03 & 2.7 & 10.8 & 10.1 & 7.2 & 10.7 & 10.1 & 7.2 \\
\hline & 試料数*1) & 8 & 8 & 8 & 22 & 8 & 8 & 22 & 8 & 8 \\
\hline & 平均 值 & 38.3 & 1.95 & 17.0 & 39.1 & 39.7 & 1.5 & 38.2 & 38.8 & 0.5 \\
\hline & 標準偏差 & 11.3 & 0.03 & 2.4 & 10.9 & 10.3 & 3.9 & 10.9 & 10.3 & 3.8 \\
\hline 普 通 & $\mathrm{N}-1$ & 23.5 & 2. 32 & 24.8 & - & - & - & - & - & - \\
\hline
\end{tabular}

*1） C-3を除いた場合

平均は $39.8 \pm 7.7 \mathrm{~N} / \mathrm{mm}^{2}$ であり, $95 \%$ 信頼限界の下限 值は $32.0 \mathrm{~N} / \mathrm{mm}^{2}$ である。表中に母平均の差の検定結 果を示すが，標準コアと小径コアの母平均に有意差は認 められない。

また，ばらつきは大きい屯のの，表-4に示したよう に，いずれの供試体においても圧縮強度は設計基準強度 である $18 \mathrm{~N} / \mathrm{mm}^{2}$ 以上であり, 構造体の強度としては 十分良好な耐久性を維持している。

2）採取位置ごとの圧縮強度

表-5 中に，標準コアおよび小径コアをまとめて，採 取位置ごとの压縮強度の母平均を推定した結果を示す。 試料数が少ないこともあり，統計的には有意とはならな いものの, 採取階, 部材および方角の違いによる圧縮強
度の差が大きい。採取階での違いは，骨材が野積みされ ていたことから，打設時の骨材の含水状態の変動の影響 が考えられる。また，柱と壁の違いは，断面の大きさの 違いによる締固め効果および打設後の乾燥程度の違いな どの影響が考えられる。方角での違いの原因はあきらか ではないが，日射等の気象条件の違いにより，打設後初 期の乾燥程度に違いが生じたことも考えられる。

\section{2 静弾性係数}

図-3に, 静弾性係数と標準コア強度の関係を示す。 図中の曲線は, 日本建築学会の「鉄筋コンクリート構造 計算規準」に示される静弾性係数の推定式に, 供試体の 単位容積質量の平均値 $1.95 \mathrm{t} / \mathrm{m}^{3}$ を代入したものである。 文献 4）によれば，日本建築学会規準式と実測值の相関 
表-5 圧縮強度の母平均の推定

\begin{tabular}{|c|c|c|}
\hline \multicolumn{3}{|c|}{ 施設全体の圧縮強度推定値 } \\
\hline & 標準コア & 小径コア \\
\hline 試 料 数 & 8 & 9 \\
\hline 平妁值 & 38.3 & 39.8 \\
\hline 槽準偏差 & 11.3 & 10.1 \\
\hline 95\%信頼区閒 & \pm 9.5 & \pm 7.7 \\
\hline 95\%信頼限界の下限值 & 28.8 & 32.0 \\
\hline 母平均の差の検定 & \multicolumn{2}{|c|}{$t_{0}=0.289<t(0.05,15)=2.131$} \\
\hline \multicolumn{3}{|c|}{ 階ごとの压縮強度推定做 } \\
\hline & $1 \mathrm{~F}$ & $2 \mathrm{~F}$ \\
\hline 試 料 数 & 8 & 9 \\
\hline 平均 值 & 35.3 & 43.0 \\
\hline 標準偏差 & 11.8 & 8.1 \\
\hline \multicolumn{3}{|c|}{ 部材ごよの圧縮強度推定值 } \\
\hline & 壁 & 柱 \\
\hline 試 料 数 & 8 & 7 \\
\hline 平均值 & 36.9 & 43.3 \\
\hline 標準偏差 & 13.5 & 6.0 \\
\hline \multicolumn{3}{|c|}{ 環境条件ごとの圧縮強度推定值 } \\
\hline & 外 部 & 内 部 \\
\hline 試 料 数 & 9 & 8 \\
\hline 平均值 & 39.2 & 38.8 \\
\hline 標淮偏差 & 8.7 & 12.6 \\
\hline \multicolumn{3}{|c|}{ 方侢ごとの生縮強度推定值 } \\
\hline & 北 面 & 南・東面 \\
\hline 試 料 数 & 8 & 9 \\
\hline 平均值 & 44.0 & 34.6 \\
\hline 標準偏差 & 10.0 & 9.0 \\
\hline
\end{tabular}

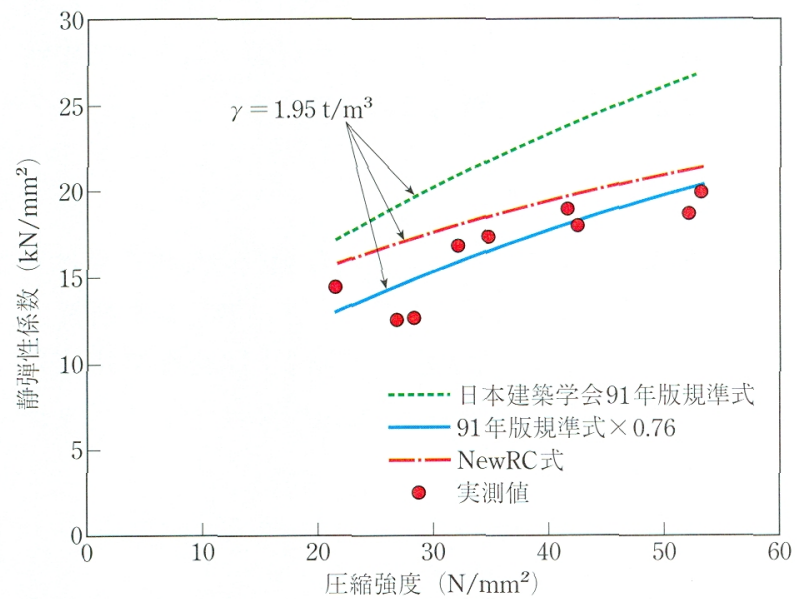

図-3 静弾性係数と標準コア強度の関係

において，軽量コンクリート 1 種の場合には 0.76 を乗 ずることによって，推定式と実測值の一致精度が向上す るとされている。図中に実線で示したものが，規準式に 0.76 を乗じたものである。実测値は実線によく一致し ており,このことから, 㓍工後 36 年経過した軽量コン クリートにおいても, 材齢 1 年程度までの軽量コンクリー 卜を試験して得られる静弾性係数とほとんど変わらない

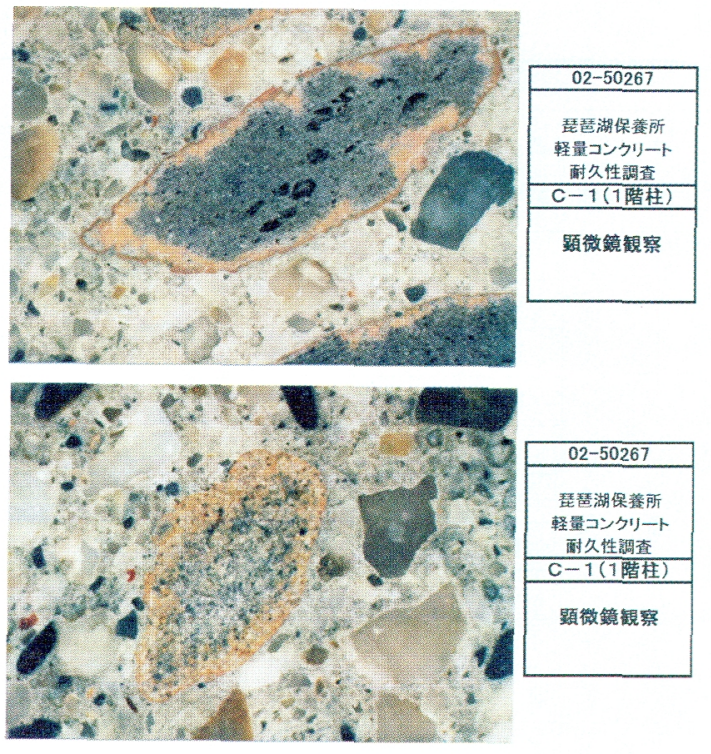

写真-5 標準コア断面の顕微鏡写真

と判断できる。

\section{3 顕微鏡観察}

写真-5 に, 標準コア断面の顕微鏡写真を示す。コア 断面にひび割れ等の異常は認められなかった。コンクリー 卜の静弾性係数は経年とともに, 乾燥やマイクロクラッ クの発生等により低下することがあるとされているが, 本調査に打ける軽量コンクリートにおいては，ひび制れ も認められないこと，扔よび静弾性係数が 1 年程度の材 齢初期のレベルを維持していることなどから，劣化はほ とんど進行していないと判断される。

\section{4 中 性 化}

（1）施設全体の中性化深さ

表-6に，中性化深さの測定結果を示す。標準コアの 嘍裂面での測定值でみると, 屋外環境下のモル夕ル仕上 げの箇所での中性化深さは最大で $7 \mathrm{~mm}$ 程度で, 中性 化はほとんど進行していない。中性化抑制効果の小さい 仕上げを施してある屋内の W-2 および W-5 における中 性化深さは， $12.5 \mathrm{~mm}$ 扎よび $20.0 \mathrm{~mm}$ であったが，か ぶり厚さの範囲内であり, 鉄筋の発錆等は認められず, 健全な状態であった。

\section{（2）小径コア上標準コアの中性化深さの関係}

図-4に，調查位置ごとの中性化深さを示す。図中の 小径コアによる中性化深さは, 調查部位ごとの平均値で 示した。

小径コアによる中性化深さと割裂面で測定した標準コ アによる中性化深さの差は最大で $7.1 \mathrm{~mm}$ であり，試 験結果はほぼ一致する。

また，小径コアの 1 調査部位から無作為に 1 個抽出し た中性化深さの平均值は $6.0 \mathrm{~mm}$ で，調査部位ごとの 平均值 $5.7 \mathrm{~mm}$ とほぼ等しいことから，小径コアを用 いて中性化深さを測定する場合には，標準コアと同じ試 料数を用いれば実用上問題はないといえる。

以上のことから，圧縮強度と同様に，中性化深さにつ 
表-6 中性化深さの測定結果

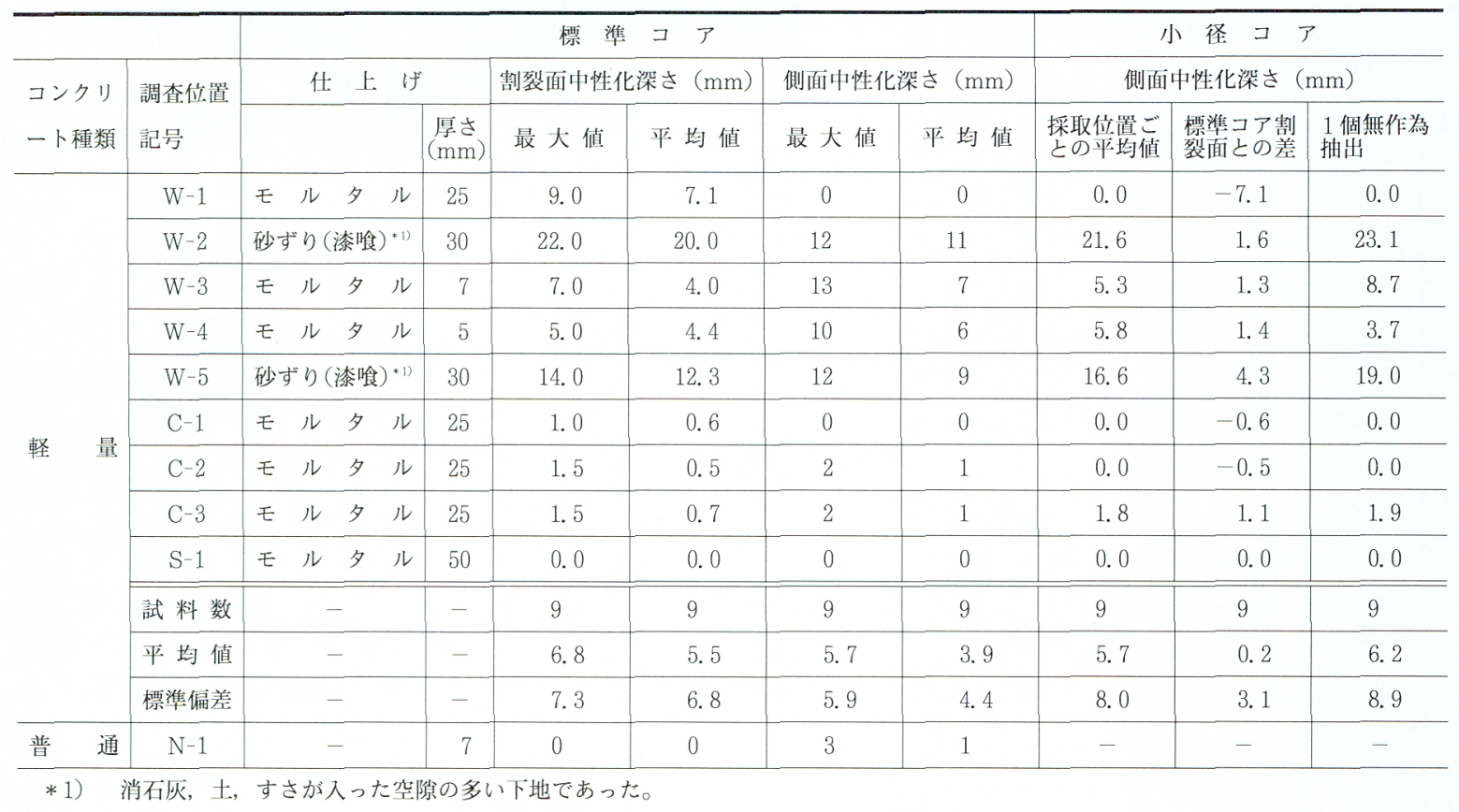

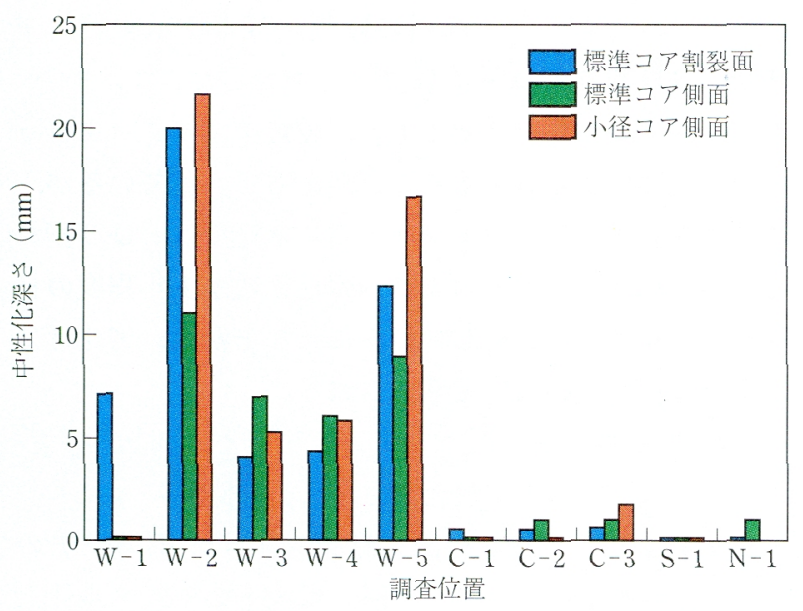

図-4＼cjkstart調査位置ごとの中性化深さ

いてむ小径コアを用いて実用的な精度で評価できると考 えられる。

\section{4.まとめ}

本調査により得られた知見を以下にまとめる。

(築造後 36 年を経過した軽量コンクリートの耐久性)

1）壁，柱抢よび床から採取したコア供試体の圧縮強 度は，いずれの供試体においても設計基準強度 18 $\mathrm{N} / \mathrm{mm}^{2}$ 以上を有しており, 構造体の強度としては 十分良好な耐久性を維持していた。

2）各供試体の静弾性係数は材齢 1 年程度までの軽量 コンクリートを試験して得られる静弾性係数とほほ 同程度で，経年による低下は認められず，十分良好 な耐久性を維持していた。

3）中性化深さは，仕上げの種類により異なり，モル タル仕上げの部分での中性化はほとんど進行してい
なかった。

中性化抑制効果の小さい仕上げの部分では，20 $\mathrm{mm}$ 程度の中性化が認められたが，かぶり厚さの 範囲内であり，鉄筋の発錆は認められなかった。 (小径コア手法の軽量コンクリートへの適用性)

4）軽量コンクリートに扔ける小径コアと標準コアの 強度の関係は，普通コンクリートの場合とほぼ同様 であり，軽量コンクリートについても普通コンクリー 卜と同様の方法で，小径コアにより構造体コンクリー 卜強度の推定が可能である。

5）中性化深さに関しても，小径コアと標準コアの試 験值がほぼ等しいことから，小径コアによって中性 化深さを実用的な精度で評価できる。

5. おわりに

本調査は，太平洋セメント(㑣より施設の提供を受け人 工軽量骨材 (ALA) 協会およびソフトコアリング研究会 (㑣錢高組，前田建設工業㑣)，日本国土開発㑣)で構成） が共同して行ったものである。ご協力いただいた方々に 深く感謝いたします。

$$
\text { 参 考 文 献 }
$$

1）大久保孝昭・長谷川拓哉・濱崎 仁・杉山 央・上村克郎・友澤 史紀・飛坂基夫：長期間暴露された人工軽量骨枌コンクリートの 諸性状，日本建築学会構造系論文集，No. 561，pp. 23～29，2002. 11

2）寺田謙一・谷川恭雄・中込 昭・佐原啨也：小径コアによる構造 体コンクリート強度の推定方法, コンクリート工学, Vol. 39, No. 4 , pp. 27〜32, 2001. 4

3）若林信太郎・谷川恭雄・中込 昭・佐原鲭也・寺田謙一：小径コ アによる構造体コンクリート強度の推定方法に関する研究（その 2 : 構造体コンクリート強度推定式の設定), 日本建築学会構造系 論文集，No. 561，pp. 9 18，2002.11

4）人工軽量骨材 (ALA) 協会：技術資料 No. $5,1988.5$ 